Article

\title{
Exploring Key Competencies of Mid-Level Academic Managers in Higher Education in Vietnam
}

\author{
Thuan Van Pham ${ }^{1}\left(\right.$, Thanh Thi Nghiem ${ }^{1,2}, *$, Loc My Thi Nguyen ${ }^{1}$, Thanh Xuan Mai ${ }^{2} \mathbb{C}$ and \\ Trung Tran ${ }^{3, *(1)}$ \\ 1 VNU University of Education, Vietnam National University, Hanoi 100000, Vietnam; \\ thuanpv@vnu.edu.vn (T.V.P.); locntm@vnu.edu.vn (L.M.T.N.) \\ 2 Hanoi National University of Education, Hanoi 100000, Vietnam; thanhmx@hnue.edu.vn \\ 3 Vietnam Academy for Ethnic Minorities, Hanoi 100000, Vietnam \\ * Correspondence: nghiemthithanh@vnu.edu.vn(T.T.N.); trantrung@hvdt.edu.vn (T.T.)
}

Received: 10 October 2019; Accepted: 26 November 2019; Published: 1 December 2019

\begin{abstract}
Vietnamese higher education has been subjected to constant pressures and major changes in the last few decades so as to meet the country's needs for socio-economic development and to better prepare graduates for employment and personal growth. There has been greater recognition for the role of mid-level academic managers as key contributors to effective institutional performance and success. However, an understanding of what constitutes a competent mid-level academic manager, who are heads of faculties, departments, academic offices and specialized centers, for the context of Vietnam is limited. This study employs an exploratory and mixed-method approach to identify the core competencies required for mid-level academic managers at Vietnamese higher education institutions. Findings from focus group discussions and a survey conclude five professional domains for effective mid-level academic management and sustainable development yet, in the meantime, reveal the gap between institutional expectations and the actual competencies of academic heads as perceived by academic heads themselves, their supervisors and their team members.
\end{abstract}

Keywords: competency; heads of department; mid-level academic managers; mid-level management; higher education; sustainable development

\section{Introduction}

The higher education sector around the world has undergone profound changes in their missions and functions, fueled by accelerating globalization, technological advances [1-5], and public demands for accountability. To respond effectively to new demands and create a sustainable educational environment, management at all levels at higher education institutions (HEI) has begun to gain a greater awareness of their roles and missions than in the past [6], when the focus on leadership and management at higher education institutions has mostly been on top executives. However, previous studies suggest that what occurs at the mid-level, who are heads/directors of faculties, departments, academic offices, and in some cases research centers, contribute more significantly to institutional performance rather than those at the top [7-12]. Commenting on how the success and competitiveness of higher education institutions necessarily requires the effective functioning of mid-level academic management, Jones [13] argues that "there is no way in which the university's expectations will be realised if HODs [head of departments] as 'middle managers' are unable or unwilling to put them into action" [13].

As a developing country with demands of a skilled and competitive workforce, Vietnam has placed a great emphasis and made an extensive investment in upholding its tertiary education [14]. Improving institutional governance is among highly discussed topics in governmental and institutional 
policies; yet, mid-level academic leadership and management are still under-researched, despite their importance for the sustainability of the Vietnamese academic system for the future. To the best of our understanding, a formal and quality understanding of what constitutes a competent mid-level manager for the context of Vietnam is limited. Recently, the Prime Minister of Vietnam has launched a national project to improve the quality of managers of higher education institutions in the 2019-2030 period [15]. This project has been central to the needs to meet the requirements of fundamental and comprehensive innovation in education and training. Furthermore, Vietnam education is also growing in fast pace, with significant rise in the position of Vietnam universities in the university rankings and scientific output [16-18], the quality of the leadership and management will contribute significantly to maintain the momentum of the development, as well as setting the conditions for future sustainability.

This paper seeks to highlight the competencies that are necessary for mid-level academic managers at Vietnamese universities. The study employs a mix of methods including content analysis, focus group interview, and survey to identify the core competencies required by heads of faculties, departments, academic offices and specialized centers. The findings from focus group interview and survey conclude five professional domains for effective mid-level academic management. Moreover, it also reveals the gap between the expected standards and the actual competencies of academic heads as perceived by academic heads themselves, their supervisors and their team members.

\section{Literature Review}

\subsection{Mid-Level Academic Managers in a Developing Context}

A mid-level manager can be defined as the one "below the small group of top strategic managers and above first-level supervision" [19]. In an educational setting and HEIs mainly, mid-level academic managers comprise heads/directors of faculties, departments, academic offices and, in some cases, research centers that serve to connect institutional strategies and implementation $[11,20]$. The critical role of departmental level management and leadership is highlighted as academic units are the base for various day-to-day operations at higher education institutions. Wolverton et al. [21] further emphasizes that $80 \%$ of the administrative decisions in colleges and universities are performed by mid-level academic managers.

Lan [22], on reviewing the changing governance and management model at higher education institutions, noted that mid-level academic managers are the group affected most by institutional changes. However, they can face serious and genuine challenges in becoming professional academic managers who can bring about the changes needed for institutions' sustained performance [22,23]. For one thing, there is an issue of role ambiguity and role conflict [11,12,24-29] and blurring boundaries of authority and power [11,26,29-32]. For another, there is an issue of training and professional development. Different scholars have remarked on this lack of research into the professional qualities and professional development for heads of departments [13,26,27,29,33]. Nguyen [24] particularly points to the Western-biased nature of existing studies on mid-level academic managers, highlighting the need to understand mid-level academic leadership in a specific context and tradition.

Reviewing the discourses on mid-level management as early as the 1970s and the conceptualisation of middle management in higher education, Clegg and McAuley [34] found that middle managers have assumed different roles through time, originally as representatives of organisational values, then as conservative, self-directed agents of control, to more recently as transmitters of core strategic values and also agents of innovation and change in response to external changes. Traditionally, academic heads at higher education institutions are seen to be more concerned with the core academic values of their department than organisational values $[20,34,35]$. They are often elected among colleagues based on their research reputation and teaching excellence, and their leadership roles accordingly rest on their academic aspects. Therefore, heads of academic departments and offices tend to assume "the traditional academic styles of negotiation and consensus-building" [20] and the "good citizen 
chore" [20]. This has been argued to cause department heads to frequently disassociate themselves from managerial practices [34,35].

A shared perception now is that the role of academic heads nowadays is not purely operational or administrative, but "has evolved into something more strategic and empowering" [36]. Middle management is seen to be highly complex, multifaceted, multidirectional, and demands negotiation amidst networks of professional and power relations [29]. Meek, Goedegebuure, Santiago, and Carvalho [20] note that middle managers at institutions are increasingly expected to possess management capabilities, namely having the capacity to "define missions, objectives, and strategies", "manage financial and human resources", and "assume strong leadership" [20]. This is more apparent in the context of higher education institutions moving towards a corporate and autonomous model $[23,37,38]$ under shrinking public funding, privatisation, benchmarking, and greater demands for accountability. The formulation and implementation of mission statements, strategic planning and quality assurance of universities have resulted in considerable expansion for the management duties of mid-level academic heads [22].

Under a changing management context, there are different competencies that mid-level academic managers need to demonstrate. Analyses of the performance of mid-level positions in Australian, British, and US higher education institutions [11,24,39,40] identify six broad categories of tasks that academic heads have to perform, namely department governance, programme management, human resource management, budget and resources management, external communication, and office management. The skills and knowledge that tap into these key tasks, which are summarized in Table 1, have been discussed by many scholars [22,24,33,39-41]. However, articulated knowledge and skill competencies required for effective departmental leadership and management are argued to be grounded on anecdotal evidence rather than on empirical and original research [22].

Table 1. Competencies required for effective mid-level academic management.

\begin{tabular}{|c|c|}
\hline Domains & Competencies \\
\hline Department governance & $\begin{array}{l}\text { - Managing multiple roles } \\
\text { - Having a clear sense of direction and strategic vision } \\
\text { - Communicating departmental direction }\end{array}$ \\
\hline Programme management & $\begin{array}{l}\text { - Promoting high-quality teaching } \\
\text { - Promoting faculty research }\end{array}$ \\
\hline Human resource management & $\begin{array}{l}\text { - Understanding faculty recruitment policies and procedures } \\
\text { - Fostering faculty members' capacity } \\
\text { - Evaluating performance and providing feedback } \\
\text { - Treating academic staff fairly and with integrity } \\
\text { - Allowing the opportunity to participate in key decisions } \\
\text { - Making academic appointments }\end{array}$ \\
\hline Budget and resources management & $\begin{array}{l}\text { - Understanding internal and external sources of funds } \\
\text { - Providing resources to stimulate scholarship and research }\end{array}$ \\
\hline External communication & $\begin{array}{l}\text { - Interpersonal skills } \\
\text { - Communicating effectively } \\
\text { - Promoting the department's image }\end{array}$ \\
\hline Office management & $\begin{array}{l}\text { - } \text { Decision-making } \\
\text { - Resolving conflicts } \\
\text { - } \text { Maintaining faculty morale } \\
\text { - Creating a positive/collegial work atmosphere }\end{array}$ \\
\hline
\end{tabular}

\subsection{Mid-Level Academic Management in the Vietnamese Context}

To the best of our knowledge, research studies on leadership and management for the higher education sector in Vietnam are significantly underdeveloped [22,42]. There is a limited number of empirical studies on mid-level academic management, particularly on how-to training and improving the quality of department managers and leaders at a university. Based on the data of the responsibilities of heads of departments at Vietnamese universities, research studies found that Vietnamese mid-level 
academic managers act on three key areas: programme management, academic staff management, and facilities management $[24,33]$. The areas that are often neglected as a result of role ambiguity and a low level of autonomy are strategic management, budget management, external relationship management, personal academic activities, and management of students and administrative staff. Vietnamese heads of departments often assume more of a generic managerial role-being more concerned with operational, day-to-day matters-than a leader's role with strategic planning and thinking forward to the future.

\section{Methods}

\subsection{Research Methods}

This study employed a combination of content analysis, focus group interview, and survey to identify the key competencies and provide a competency framework for Vietnamese mid-level academic managers to thrive under the drastic change of the higher education system.

First, literature about mid-level academic managers was reviewed to identify the characteristics and the common tasks of a mid-level academic managers. We hsearched with keywords such as mid-level academic managers, academic managers, higher education management, and middle academic managers to identify a collection of suitable materials. The materials were divided evenly among the research team. Each member had to review the literature carefully and to check others' reviews as well. Based on the literature review, the characteristics and the common tasks of Vietnam mid-level academic managers were determined by using job descriptions from seven Vietnamese universities. Content analysis was conducted to determine similarities and differences in these job descriptions to identify key management areas and required competencies of department managers.

Then, focus group interviews were conducted with Vietnam mid-level academic managers at seven universities to seek their opinions on the essential competencies to perform effectively. During the focus group interviews, a list of tasks, which was based on the analysis of job description, was provided. The interviewees were then asked to comment on the tasks in the list; and provide some necessary competencies that are required for performing each task. Eventually, a list of competencies that were required for mid-level academic managers at Vietnamese universities was finalized and then converted into a questionnaire. Nineteen competencies were identified as the potential competencies that were important for mid-level academic managers at Vietnamese universities (Table 2). These competencies were put into five areas: Leadership and management, Administration, Advising and consultation, Human resources management, and Self-management.

Table 2. Competency areas required of mid-level academic managers.

\begin{tabular}{cc}
\hline Codes & Essential Competencies \\
\hline Le & Leadership and management \\
Le1 & Leading change \\
Le2 & Managing operations \\
\hline Ad & Administration \\
Ad1 & Formulating and processing management documents \\
Ad2 & Building organisational culture \\
Ad3 & Communicating information internally \\
Ad4 & Applying information technology \\
AA & Advising and consultation \\
AA1 & Creative problem-solving; conflict management \\
AA2 & Presentation skills \\
AA3 & Negotiation skills \\
PA & Human resources management \\
PA1 & Allocating and using human resources \\
PA2 & Evaluating performance and proving feedback \\
PA3 & Coaching and mentoring \\
PA4 & Building a work environment and motivating team \\
& members \\
\hline
\end{tabular}


Table 2. Cont.

\begin{tabular}{cc}
\hline Codes & Essential Competencies \\
\hline AY & Self-management \\
AY1 & Maintaining political and ethical qualities \\
AY2 & Self-training, self-direction \\
AY3 & Interpersonal skills \\
AY4 & Collaborative skills \\
AY5 & Adapting to changes \\
AY6 & Using competently a foreign language \\
\hline
\end{tabular}

Finally, a questionnaire was distributed to mid-level academic managers, their seniors, and their faculty members to validate the list of competencies and to gain more insight into the professional practices of Vietnamese mid-level academic managers. Moreover, the essential competencies nominated for each key task were also identified by the participants. The questionnaire consisted of 38 statements with answers based on a five-point Likert scale. A score of 1 represented either the least essential competency or the competency that was not met by mid-level academic managers; meanwhile, a score of 5 represented either the most essential competency or the competency that was fully displayed by mid-level academic managers. The survey results were used for a comparison with the focus group discussions in order to come up with the final framework.

\subsection{Sampling Methods}

Note that the current governance structure in Vietnamese higher education is characterised as being heavily under state control [14]. Decision-making power stays primarily with the two national, three regional, and fourteen key universities $[43,44]$, thus depriving more than 100 other universities and provincial universities of incentives to innovate [45]. Thus, to ensure diversity, mid-level academic managers and other staff and faculty members from seven Vietnam public universities were invited to participate in the study. These universities represent different type of higher education institutions with different sizes, organizational structures, autonomy levels, and geographical locations in Vietnam,

From the northern region of Vietnam is the University of Education, a member of Vietnam National University Hanoi that reports directly to the Prime Minister and has the highest level of autonomy and decision-making power, and Hanoi National University of Education, a university that reports to the Ministry of Education and Training (MOET) and has a high level of autonomy.

From the central region of Vietnam are Vinh University, a regional university under MOET's supervision with high decision-making power, and Hong Duc University, a provincial university that reports to both MOET and provincial authority and has the lowest level of autonomy.

Representing the southern region of Vietnam are An Giang University, Ho Chi Minh University of Education, and Dong Thap University.

The authors received responses from a total of 422 respondents (212 are mid-level academic managers) from the seven universities. Details of the respondents' positions in the universities are provided in Table 3.

Table 3. Positions and the number of respondents to the questionnaire.

\begin{tabular}{cc}
\hline Positions & Number \\
\hline Rectors & 10 \\
Heads of offices & 40 \\
Deputy heads of offices and office members & 172 \\
Deans and faculty members & 200 \\
Total & 422 \\
\hline
\end{tabular}




\subsection{Data Analysis}

Responses from the survey were coded and entered in the statistical software SPSS (Version 20) and checked for reliability using the Cronbach's $\alpha$ reliability estimate $(\alpha=\mathrm{N} \rho /[1+\rho(\mathrm{N}-1)])$. A high reliability coefficient was achieved, with the Cronbach's $\alpha$ estimates ranging from 0.746 to $0.897(\geq 0.6)$ (Table 4). The corrected item-total correlation estimates ranged between 0.5 and $0.7(>0.3)$, also showing good correlations between the variables.

Table 4. Reliability estimates of the variables.

\begin{tabular}{cccc}
\hline Factors & Observed Variables & Cronbach's $\alpha$ & Corrected Item-Total Correlation \\
\hline Le & Le1, Le2 & 0.780 & $>0.3(0.640)$ \\
Ad & Ad1, Ad2, Ad3, Ad4 & 0.820 & $>0.3(0.515-0.749)$ \\
AA & AA1, AA2, AA3 & 0.746 & $>0.3(0.502-0.672)$ \\
PA & PA1, PA2, PA3, PA4 & 0.818 & $>0.3(0.583-0.716)$ \\
AY & AY1, AY2, AY3, AY4, AY5, AY6 & 0.897 & $>0.3(0.592-0.792)$ \\
\hline
\end{tabular}

Then, an Exploratory Factor Analysis (EFA) was conducted to determine the correlation between the competencies and to determine their factor loadings. Kaiser-Meyer-Olkin (KMO) Test $=0.794$ and Sig Barlett's Test $=0.000$ (Table 5), showing good correlations between the observed variables.

Table 5. Kaiser-Meyer-Olkin (KMO) and Barlett's Test of the samples.

\begin{tabular}{ccc}
\hline \multicolumn{2}{c}{ Kaiser-Meyer-Olkin Measure of Sampling Adequacy } & 0.794 \\
\hline & Approx. Chi-Square & 3713.316 \\
Bartlett's Test of Sphericity & df & 171 \\
& Sig. & 0 \\
\hline
\end{tabular}

The loading factors $(\geq 0.509)$, as seen from the Rotated Component Matrix (Table 6), also showed good correlations between the variables.

Table 6. Rotated Component Matrix of the variables.

\begin{tabular}{|c|c|c|c|c|c|}
\hline & \multicolumn{5}{|c|}{ Component } \\
\hline & 1 & 2 & 3 & 4 & 5 \\
\hline AY2 & 0.852 & & & & \\
\hline AY5 & 0.845 & & & & \\
\hline AY3 & 0.840 & & & & \\
\hline AY4 & 0.834 & & & & \\
\hline AY6 & 0.731 & & & & \\
\hline AY1 & 0.695 & & & & \\
\hline $\mathrm{Ad} 3$ & & 0.876 & & & \\
\hline $\mathrm{Ad} 2$ & & 0.838 & & & \\
\hline Ad4 & & 0.779 & & & \\
\hline Ad1 & & 0.672 & & & \\
\hline PA2 & & & 0.858 & & \\
\hline PA3 & & & 0.818 & & \\
\hline PA1 & & & 0.752 & & \\
\hline PA4 & & & 0.739 & & \\
\hline AA2 & & & & 0.858 & \\
\hline AA3 & & & & 0.813 & \\
\hline AA1 & & & & 0.722 & \\
\hline Le1 & & & & & 0.882 \\
\hline Le2 & & & & & 0.857 \\
\hline
\end{tabular}




\section{Results and Discussions}

\subsection{Competencies Required of Vietnamese Mid-Level Academic Managers}

The mid-level academic managers of our survey were asked to rate the extent to which they agreed that each of 19 competencies was necessary for an effective performance in their role. The data collected from the survey show a high level of agreement between heads of departments, faculty members, and senior leaders with regard to the key tasks needed to be performed by academic managers at the middle level and the essential competencies required for effectively performing these tasks. The mean values for the 19 competencies ranged from 3.63 to 4.04, confirming that all the competencies were perceived by the respondents to be important or very important to mid-level academic managers. The top 10 most essential competencies required of heads of departments and offices at Vietnamese universities are spread out across the four domains as shown in Table 7. The competencies that fall under the leadership and managerial domain were considered to be indispensable for heads of departments and offices. This resonates with Eley's [6] observation that heads of departments now regard their management role as being of greater importance than in the past.

Table 7. Top 10 essential competencies required of Vietnamese academic managers.

\begin{tabular}{ccc}
\hline$\#$ & Domains & Competencies \\
\hline 1 & Leadership and management & Leading changes \\
2 & & Managing operations \\
\hline 3 & Advising and consultation & Creative problem-solving \\
4 & & Presentation skills \\
5 & Negotiation skills \\
\hline 6 & Human resources management & Evaluating performance and providing feedback \\
7 & & Coaching and mentoring \\
8 & Self-management & Maintaining political and ethical qualities \\
\hline 9 & & Self-training, self-direction \\
\hline 10 &
\end{tabular}

\subsection{Competencies of Vietnamese Mid-Level Academic Managers}

The opinions of university rectors, heads of departments, and faculty members from the participating universities about the extent to which the mid-level academic managers show their competencies were sought through the survey. The mean value range was 3.33 to 4.27 , indicating that mid-level academic managers generally possessed a satisfactory level of leadership and management capacities. Mid-level academic managers were ranked the highest in terms of the ability to self-manage, provide consultation, perform managerial duties, and deal with administrative matters. The top ten competencies that most of the heads of departments possess are presented in Table 8.

Table 8. Top 10 competencies that most of Vietnamese mid-level academic managers possess.

\begin{tabular}{ccc}
\hline$\#$ & Domains & Competencies \\
\hline 1 & & Maintaining political and ethical qualities \\
2 & Self-management & Self-training, self-direction \\
3 & & Interpersonal skills \\
4 & Collaborative skills \\
5 & Adapting to changes \\
\hline 6 & Advising and consultation & Creative problem-solving; conflict management \\
7 & & Presentation skills \\
8 & & Negotiation skills \\
\hline 9 & Leadership and management & Managing operations \\
\hline 10 & Administration & Formulating and processing management documents \\
\hline
\end{tabular}




\subsection{How Well are Mid-Level Academic Managers Performing Against the Expected Competencies?}

Comparing the mean differences, there exists a gap between the competencies required and the actual competencies displayed by Vietnamese heads of departments and offices (Figure 1). The surveyed department managers were scored lower in 17 out of 19 areas.

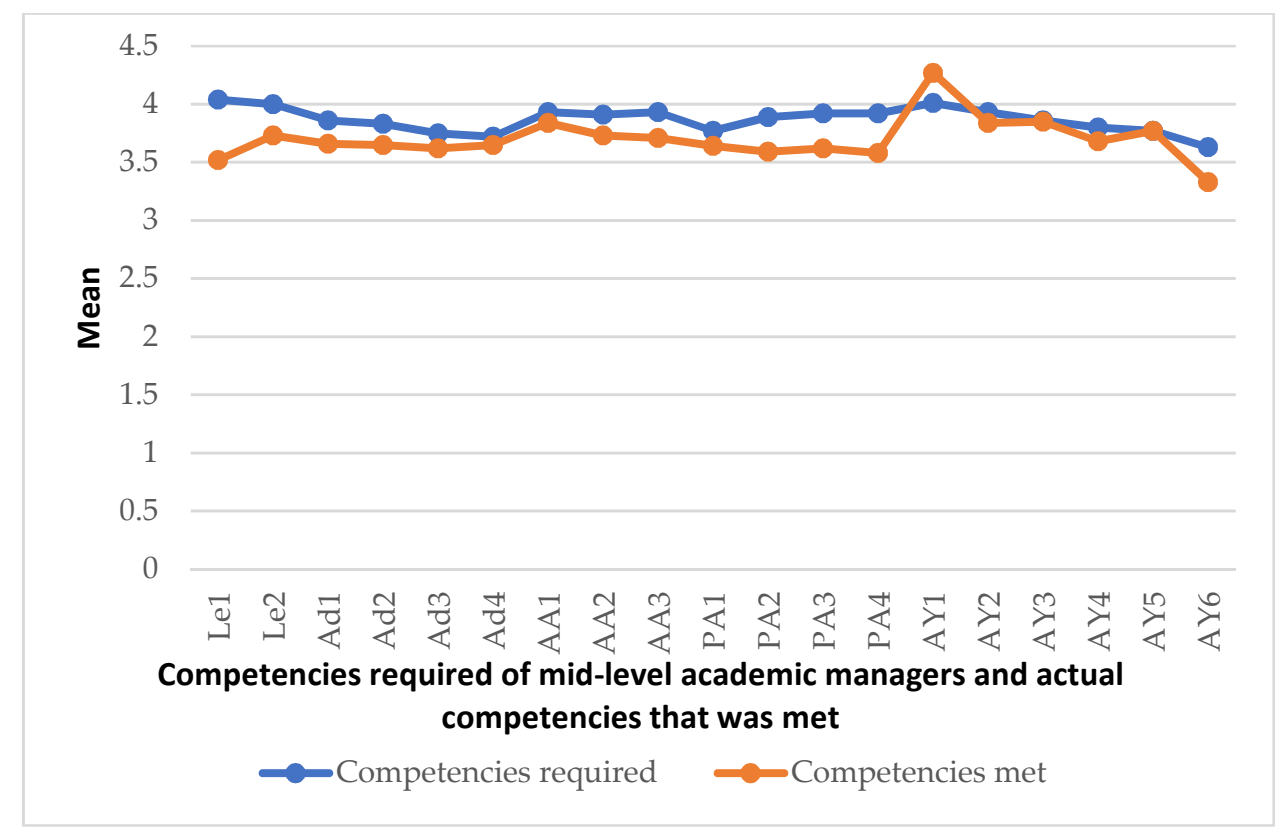

Figure 1. Competencies required of mid-level academic managers and actual competencies that were met.

The gap was the most noticeable for the capacity to lead changes [Le1] with a mean difference of 0.52 , even though this was perceived to be the most important competency needed for department heads. The ability to lead changes and manage departmental operations was perceived to be the most important quality that heads of departments and offices need to possess $\left(\mathrm{M}_{\mathrm{Le} 1}=4.04\right.$ and $\left.\mathrm{M}_{\mathrm{Le} 2}=4\right)$. For academic heads, strategic planning and leading changes necessarily mean creating visions and short and long-term goals for their department. This involves focusing the department's teaching and research priorities on areas where they can make a difference. Academic heads are expected to demonstrate this while working closely with their department's research committee, curriculum developers, and faculty members and on encouraging staff to contribute to ideas for department improvement. However, strategic management is a weak and neglected point for Vietnamese academic managers. Middle managers were more competent with day-to-day operational matters and ensuring that their unit functioned effectively, rather than with developing strategic planning and setting the vision for there the unit will head. This study found that academic managers often lacked the training, resources, and power they need to lead and drive changes. This resonates with Gallos's [46] comment that department-level managers at higher education institutions "have enormous responsibilities" yet "little positional power, insufficient resources, and limited authority" [46].

In the context of Vietnamese higher education, for one thing, this is highly attributable to the limited autonomy that institutions and faculties themselves can enjoy [14,47]. The functions and responsibilities of mid-level academic managers in Vietnam are still conceptualised under the state steering of higher education systems. Despite government initiatives to reform institutional governance, public universities in Vietnam remain heavily dependent on state funding to sustain their personnel, curriculum, and infrastructure [47-50]. MOET prescribes and monitors admission quotas, recruitments of academics, and curricular development. The capacity of middle managers to exert their authority and influence is therefore constrained under state centralisation and decision-making processes, which are characterised as being hierarchical and top-down [48]. For another thing, the low self-perceived 
ability to drive changes by mid-level academic managers is a result of a so-called survival culture that Vietnamese universities and academic departments have for long adopted. As observed by Salmi [48], the majority of faculties only react to changes when they are forced to go. Therefore, to empower mid-level academic managers to assume a more effective leadership and managerial position, in addition to advocating more institutional and departmental autonomy, heads of units should be encouraged to be proactive and responsive in making department decisions. Lan [22] argued that heads of units should be required to make strategic development plan for their department and given the authority over staff recruitment and budget management.

The next professional areas that department heads were seen to fall behind the standards were the ability to evaluate performance and provide feedback, coach, and mentor, and build a facilitative work environment and motivate team members (PA2, PA3, and PA4). Despite the importance of human resources to the functioning of any organisations, the recruiting, mentoring, coaching, and evaluating the performance of team members were perceived to be not as important as other competencies expected and displayed by mid-level academic managers [51]. This points to the lack of departmental and institutional autonomy. With regard to the recruitment of team members, although heads of departments were often involved in the staff recruitment process, their authority was only extended to making recommendations for senior managers, mostly the rector and human resource manager, to decide on the candidate to be selected. Subject to the statement management of public universities, department heads could not also dismiss a team member who did not perform well if the employee had been awarded an official employment status. It is therefore apparent that the role of mid-level academic managers from Vietnamese universities with regard to developing department-level human resources was confined to following and obeying instructions from senior managers.

In the group of administrative competencies, the capacity to build the departmental culture, communicate information to team members, and apply ICT were not ranked very high as the competencies required of $(M=3.77)$ and displayed $(M=3.64)$ by academic managers. Only the capacity to develop and process management documents was ranked as highly important to effective departmental management. It was generally agreed that this is an essential part of the administrative tasks that heads of units have to assume. Bolton [52] argued that department leaders in the US and European universities often find it difficult to maintain their administrative presence as they are already overloaded with multiple tasks and duties. Moreover, it was also difficult for the mid-level managers to persuade and attain the consensus among their staff, such as in UK universities [53]. The situation for the Vietnamese universities surveyed was that most department leaders had to act simultaneously in the role of a lecturer, a researcher, and an administrator. Most emphasis was still being placed on the teaching competencies of faculty heads, leaving inadequate attention to their role in overseeing administrative tasks.

The capacity to self-manage has been considered a fundamental requirement for empowering both individual and organisational success and is placed at the core of leadership [54,55]. According to Rothstein and Burke [55], self-management is the foundation of "introspection, choice, priority setting, change, and development" [55]. It can be seen not only in an individual's ability to adapt to changes but also in their interpersonal and collaborative skills and their self-directed capacity. In this study, department heads were perceived to be competent in most competencies under the self-management domain. The two areas that department heads felt to be performing at or above the standards are the ability to adapt to changes [AY5] and maintain their political and ethical qualities [AY1]. The ability of the managers to maintain political and ethical qualities $(\mathrm{M}=4.27)$ was the strongest competency that Vietnamese heads of departments and offices were seen to display. This points to the fact that professional competencies of Vietnamese managers are influenced and conditioned by the country's socio-political profile. The conception of laws and regulations for Vietnam's higher education is linked to the country's Socialist ideologies [56,57]. Institutional and department activities are formulated and implemented under the guidance of the Communist Party of Vietnam, and the educational direction of training programmes is often exercised as an administrative instrument of the Party $[57,58]$. 
The ability to use competently a foreign language [AY6] was seen to be the weakest among all the competencies. This was also an area that was perceived to be of the least significance to the performance and effective functioning of mid-level academic managers. For departmental management, the ability to communicate in English is necessary. Only academic heads who were in charge of international and foreign cooperation activities claimed to have the opportunity to use a foreign language and develop their foreign language skills. This means other heads of offices that deal with operational matters did not have the opportunity to use a foreign language at work. However, in the context of integration and internationalisation, in order for higher education institutions to enhance their competitiveness and the quality of their training, middle-academic managers need to improve their foreign language ability. This has important meaning, especially when the trend to internationalise faculties and curriculum is increasingly popular.

\section{Conclusions and Recommendations}

The identification of the core competencies for mid-level academic managers at Vietnamese universities provides useful guidance for identifying professional development needs and designing training and professional development programs for current and future mid-level academic managers. They are also useful for middle managers themselves to consider when they are reviewing and revising managerial competencies, skills or knowledge requirements. The study reveals that the management and leadership duties of middle managers are context-based and influenced by the country's socio-cultural profiles. Although academic managers are expected to assume six groups of competencies, they are self-perceived or perceived to be more competent to self-manage and perform day-to-day administration and consultation tasks.

Our analysis also shows that the ability to competently deploy foreign languages [AY6] was seen to be the weakest among all the competencies, which suggests as Vietnam's economy and higher education become increasingly internationalized, mid-level academic managers are not up to language-requirement standard. Another important result was that department heads felt that their strategic management skills were found to be a weak and neglected area. Previous studies have highlighted this weakness can be traced to the lack of institutional autonomy of academic managers in the context of Vietnamese higher education $[24,33]$. Finally, the ability to evaluate performance and provide feedback, coach, and mentor, and build a facilitative work environment and motivate team members (PA2, PA3, and PA4) was not of high standard. Of the weaknesses, language competency seems to be the easiest area to be fixed, yet, once improved it can allow mid-level managers to access to much wider pool of knowledge and opportunities. The Vietnamese government has tried to give the higher education sector more institutional autonomy, which means future studies can build on the results presented here to evaluate the progress of Vietnamese mid-level managers' strategic management skill and coaching skills. However, the mid-level managers still need to be proactive in overcoming the shortcomings and seize the opportunities in the current developing context in Vietnam [59]. Furthermore, the gap between the expected and actual standards has important implications for the training and retraining of heads of departments and offices in Vietnamese universities.

Mid-level academic managers in Vietnam universities is currently having a significant role in the development of higher education and science in Vietnam, and their contributions will be even more important for a sustainable future of the higher education system in Vietnam. Education in Vietnam is growing fast with the introduction and rising of a generation of new and financially abundant private universities, as well as new policies that enforce a new standard [16]. However, the new changes will pose new challenges for university heads, and indeed, heads of departments and offices. These findings will help the universities and education policymakers to understand the current situation, and build plans to provide a stable environment for the university, as well as Vietnam education, to thrive sustainably.

Author Contributions: Conceptualization, T.V.P.; methodology, T.T.; writing—original draft preparation, T.T.N.; writing—review and editing, T.X.M.; supervision, L.M.T.N. 
Funding: This research received no external funding.

Acknowledgments: We sincerely thank the reviewers for their valuable comments, which helped us improve the quality of the paper.

Conflicts of Interest: The authors declare no conflict of interest.

\section{References}

1. Tran, T.; Le, T.-T.-H.; Nguyen, T.-T.; Pham, A.-G.; Vu, T.-H.; Nguyen, M.-H.; Vuong, H.-M.; Vuong, T.-T.; Hoang, P.-H.; Ho, M.-T.; et al. The relationship between birth order, sex, home scholarly culture and youths' reading practices in promoting lifelong learning for sustainable development in Vietnam. Sustainability 2019, 11, 4389. [CrossRef]

2. Le, T.-T.-H.; Tran, T.; Trinh, T.-P.-T.; Nguyen, C.-T.; Nguyen, T.-P.-T.; Vuong, T.-T.; Vu, T.-H.; Bui, D.-Q.; Vuong, H.-M.; Hoang, P.-H.; et al. Reading habits, socioeconomic conditions, occupational aspiration and academic achievement in Vietnamese junior high school students. Sustainability 2019, 11, 5113. [CrossRef]

3. Trinh, T.P.T.; Pham, T.V.; Cao, H.T.; Nguyen, T.-T.; Nghiem, T.T.; Tran, T. The profile of professional standards for secondary school principals in Vietnam. Int. J. Educ. Pract. 2019, 7, 310-323. [CrossRef]

4. Thao, T.T.P.; Thai, L.D.; Thanh, H.T.; Tran, T.; Trinh, L.T.T.; Vuong, Q.-H. Mobile learning for high-school mathematics as a path to better sustainability in a fast-changing society: An exploratory study from Vietnam. Probl. Perspect. Manag. 2019, 17, 392-403. [CrossRef]

5. Trung, T.; Tien-Trung, N.; Thao, T.T.P.; Hien, L.T.T. Does education improve employee benefits in Vietnam? The first evidence from matched employer-employee data. Cogent Educ. 2019, 6, 1662162. [CrossRef]

6. Eley, A. Management training for the university head of department. Int. J. Educ. Manag. 1994, 8, $20-22$. [CrossRef]

7. Currie, G.; Procter, S.J. The antecedents of middle managers' strategic contribution: The case of a professional bureaucracy. J. Manag. Stud. 2005, 42, 1325-1356. [CrossRef]

8. de Boer, H.; Goedegebuure, L.; Meek, V.L. The changing nature of academic middle management: A framework for analysis. In The Changing Dynamics of Higher Education Middle Management; Meek, V.L., Goedegebuure, L., Santiago, R., Carvalho, T., Eds.; Springer: New York, NY, USA, 2010; pp. 229-241.

9. Pechar, H. Academic middle managers under the new governance regime at Austrian universities. In The Changing Dynamics of Higher Education Middle Management; Meek, V.L., Goedegebuure, L., Santiago, R., Carvalho, T., Eds.; Springer: New York, NY, USA, 2010; pp. 15-30.

10. Balogun, J. From blaming the middle to harnessing its potential: Creating change intermediaries. Br. J. Manag. 2003, 14, 69-83. [CrossRef]

11. Kallenberg, T. Academic middle managers shaping the landscape between policy and practice. In Diversity and Excellence in Higher Education: Can the Challenges Be Reconcilled? Pritchard, R.M.O., Klumpp, M., Teichler, U., Eds.; Sense Publishers: Rotterdam, The Netherlands, 2015; pp. 201-216.

12. Floyd, A.; Dimmock, C. 'Jugglers', 'copers' and 'strugglers': Academics' perceptions of being a head of department in a post-1992 UK university and how it influences their future careers. J. High. Educ. Policy Manag. 2011, 33, 387-399. [CrossRef]

13. Jones, G. Academic leadership and departmental headship in turbulent times. Tert. Educ. Manag. 2011, 17, 279-288. [CrossRef]

14. Le, K.A.T.; Hayden, M.; Nhan, T.T. Development of the higher education sector in Vietnam. In Quality Assurance in Vietnamese Higher Education: Policy and Practice in the 21st Century; Nguyen, C.H., Shah, M., Eds.; Palgrave Macmillan: London, UK, 2019; pp. 1-23.

15. The Prime Minister. Đề án Nâng cao năng lực đội ngũ giảng viên và cán bộ quản lý các cơ sở giáo dục đại học đáp úng yêu cầu đổi mới căn bản, toàn diện giáo dục và đào tạo giai đoạn 2019-2030 [Project on Improving the Capacity of Lecturers and Managers of Higher Education Institutions to Meet the Requirements of Fundamental and Comprehensive Innovation in Education and Training in the 2019-2030 Period]; The Prime Minister: Hanoi, Vietnam, 2019.

16. Nguyen, H.-K.T.; Nguyen, T.-H.T.; Ho, M.-T.; Ho, M.-T.; Vuong, Q.-H. Scientific publishing: The point of no return. In The Vietnamese Social Sciences at a Fork in the Road; Vuong, Q.-H., Tran, T., Eds.; Sciendo De Gruyter: Warsaw, Poland, 2019; pp. 143-162. [CrossRef] 
17. Nguyen, T.-T.; La, V.-P.; Ho, M.-T.; Nguyen, H.K.T. Scientific publishing: A slow but steady rise. In The Vietnamese Social Sciences at a Fork in the Road; Vuong, Q.-H., Tran, T., Eds.; Sciendo De Gruyter: Warsaw, Poland, 2019; pp. 33-51. [CrossRef]

18. Adams, J.; Pendlebury, D.; Rogers, G.; Szomszor, M. Global Research Report-South and East Asia; Institute for Scientific Information: Philadelphia, PA, USA, 2019.

19. Dopson, S.; Risk, A.; Stewart, R. The changing role of the middle manager in the United Kingdom. Int. Stud. Manag. Organ. 1992, 22, 40-53. [CrossRef]

20. Meek, V.L.; Goedegebuure, L.; Santiago, R.; Carvalho, T. (Eds.) The Changing Dynamics of Higher Education Middle Management; Springer: New York, NY, USA, 2010.

21. Wolverton, M.; Ackerman, R.; Holt, S. Preparing for leadership: What academic department chairs need to know. J. High. Educ. Policy Manag. 2005, 27, 227-238. [CrossRef]

22. Nguyen, H.T.L. Identifying the Training Needs of the Heads of Departments at a Newly Established University in Vietnam; The University of Melbourne: Melbourne, Australia, 2009.

23. da Motta, M.V.; Bolan, V. Academic and managerial skills of academic deans: A self-assessment perspective. Tert. Educ. Manag. 2008, 14, 303-316. [CrossRef]

24. Nguyen, H.T.L. Middle-level academic management: A case study on the roles of the heads of department at a Vietnamese university. Tert. Educ. Manag. 2013, 19, 1-15. [CrossRef]

25. Briggs, A.R.J. Facilitating the role of middle managers in further education. In Leading People and Teams in Education; Kydd, L., Anderson, L., Newton, W., Eds.; Paul Chapman Publishing: London, UK, 2003; pp. 199-214.

26. Carroll, M. The Complexity of Change for Heads of Department in New Zealand Universities. Master's Thesis, Auckland University of Technology, Auckland, New Zealand, 2018.

27. Franken, M.; Penney, D.; Branson, C. Middle leaders' learning in a university context. J. High. Educ. Policy Manag. 2015, 37, 190-203. [CrossRef]

28. Hotho, S. Higher education change and its managers: Alternative constructions. Educ. Manag. Adm. Leadersh. 2013, 41, 352-371. [CrossRef]

29. Marshall, S. Educational middle change leadership in New Zealand: The meat in the sandwich. Int. J. Educ. Manag. 2012, 26, 502-528. [CrossRef]

30. Kallenberg, A.; Studentzaken, O. Innovating in the 'patchwork' university. The balancing act of academic middle managers in and between the micro-cultures of the interacting spheres. In Proceedings of the EFMD Higher Education Research Conference, Innovations in Higher Education, IESE Business School, University of Navarra, Pamplona, Spain, 10-11 October 2016.

31. Branson, C.M.; Franken, M.; Penney, D. Middle leadership in higher education: A relational analysis. Educ. Manag. Adm. Leadersh. 2016, 44, 128-145. [CrossRef]

32. Preston, D.; Price, D. 'I see it as a phase: I don't see it as the future': Academics as managers in a United Kingdom university. J. High. Educ. Policy Manag. 2012, 34, 409-419. [CrossRef]

33. Nguyen, H.T.L. Identifying the training needs of heads of department in a newly established university in Vietnam. J. High. Educ. Policy Manag. 2012, 34, 309-321. [CrossRef]

34. Clegg, S.; McAuley, J. Conceptualising middle management in higher education: A multifaceted discourse. J. High. Educ. Policy Manag. 2005, 27, 19-34. [CrossRef]

35. Hancock, N.; Hellawell, D.E. Academic middle management in higher education: A game of hide and seek? J. High. Educ. Policy Manag. 2010, 25, 5-12. [CrossRef]

36. Bolden, R.; Petrov, G.; Gosling, J. Developing Collective Leadership in Higher Education; Leadership Foundation for Higher Education: London, UK, 2008.

37. Shattock, M. Managing Good Governance in Higher Education; McGraw-Hill Education: Maidenhead, Berks, UK, 2006.

38. Carvalho, T.; Santiago, R. New public management and 'middle management': How do deans influence institutional policies? In The Changing Dynamics of Higher Education Middle Management; Meek, V.L., Goedegebuure, L., Santiago, R., Carvalho, T., Eds.; Springer: New York, NY, USA, 2010; pp. 165-196.

39. Berdrow, I. King among kings: Understanding the role and responsibilities of the department chair in higher education. Educ. Manag. Adm. Leadersh. 2010, 38, 499-514. [CrossRef]

40. Filan, G.L.; Seagren, A.T. Six critical issues for midlevel leadership in postsecondary settings. New Dir. High. Educ. 2003, 124, 21-31. [CrossRef] 
41. Arimoto, A. University Reforms and Academic Governance Reconsidered: Report of the Six-Nation Higher Education Research Project; Research Institute for Higher Education, Hiroshima University: Higashi-Hiroshima, Japan, 2002.

42. Asian Development Bank. Southeast Asia Department Working Paper June 2012: Vietnam-Education and Training Sector Assessment, Strategy, and Roadmap. 2012. Available online: https://www.adb.org/sites/ default/files/linked-documents/cps-vie-2012-2015-ssa-09.pdf (accessed on 6 October 2019).

43. Le, Q.M. Good governance in higher education: Concepts, implement and training. In Proceedings of the DIES Conference: Strengthening Universities, Enhancing Capacities-Higher Education Management for Development, Bonn, Germany, 28-29 November 2011.

44. Do, M.H. Towards more flexible organisation. In Higher Education in Vietnam: Flexibility, Mobility and Practicality in the Global Knowledge Economy; Tran, T.L., Marginson, S., Do, M.H., Do, T.N.Q., Le, T.T.T., Nguyen, T.N., Vu, T.P.T., Pham, N.T., Nguyen, T.L.H., Ho, T.H.T., Eds.; Palgrave Macmillan: New York, NY, USA, 2014; pp. 54-84.

45. Nhan, T.T.; Nguyen, H.C. Quality challenges in transnational higher education under profit-driven motives: The Vietnamese experience. Issues Educ. Res. 2018, 28, 138-152.

46. Gallos, J.V. The dean's squeeze: The myths and realities of academic leadership in the middle. Acad. Manag. Learn. Educ. 2002, 1, 174-184. [CrossRef]

47. Dao, K.V. Key challenges in the reform of governance, quality assurance, and finance in Vietnamese higher education-A case study. Stud. High. Educ. 2015, 40, 745-760. [CrossRef]

48. Salmi, J. Academic governance and leadership in Vietnam: Trends and challenges. J. Int. Comp. Educ. (JICE) 2019, 8, 103-118. [CrossRef]

49. Pham, T.N.; Goyette, K. Higher education governance in Vietnam: Statism versus institutional autonomy. In Transformations in Higher Education Governance in Asia: Policy, Politics and Progress; Jarvis, D.S.L., Mok, K.H., Eds.; Springer: Singapore, 2019; pp. 197-212.

50. Tran, T.T. Governance in higher education in Vietnam-A move towards decentralization and its practical problems. J. Asian Public Policy 2014, 7, 71-82. [CrossRef]

51. Nguyen, H.C. An investigation of professional development among educational policy-makers, institutional leaders and teachers. Manag. Educ. 2019, 33, 32-36. [CrossRef]

52. Bolton, A. The leadership challenge in universities: The case of business schools. High. Educ. 1996, 31, 491-506. [CrossRef]

53. Hellawell, D.; Hancock, N. A case study of the changing role of the academic middle manager in higher education: Between hierarchical control and collegiality? Res. Pap. Educ. 2001, 16, 183-197. [CrossRef]

54. Kumar, S.; Adhish, V.S.; Chauhan, A. Managing self for leadership. Indian J. Community Med. 2014, 39, 138-142. [CrossRef] [PubMed]

55. Rothstein, M.G.; Burke, R.J. Self-Management and Leadership Development; Edward Elgar Publishing: Cheltenham, UK, 2010.

56. Pham, N.D. Confucianism and the conception of the law in Vietnam. In Asian Socialism and Legal Change: The Dynamics of Vietnamese and Chinese Reform; Gillespie, J., Nicholson, P., Eds.; ANU E Press and Asia Pacific Press: Canberra, Australia, 2005; pp. 76-90.

57. George, E. Socialist ideology and practical realism: The process of compromise in Vietnam's law on education. In Asian Socialism and Legal Change: The Dynamics of Vietnamese and Chinese Reform; Gillespie, J., Nicholson, P., Eds.; ANU E Press and Asia Pacific Press: Canberra, Australia, 2005; pp. 115-134.

58. Truong, T.D.; Hallinger, P. Exploring cultural context and effective school leadership: Conceptualizing an indigenous model of school leadership in Vietnam. J. Leadersh. Educ. 2017, 20, 539-561. [CrossRef]

59. Vuong, Q.-H. Breaking barriers in publishing demands a proactive attitude. Nat. Hum. Behav. 2019, 3, 1034. [CrossRef]

(C) 2019 by the authors. Licensee MDPI, Basel, Switzerland. This article is an open access article distributed under the terms and conditions of the Creative Commons Attribution (CC BY) license (http://creativecommons.org/licenses/by/4.0/). 